\title{
The Developmental Stages of the Child in the Foundation Phase: Partnership
}

\author{
Swanki Stephinah Senosi
}

\author{
Department of Early Childhood Education: University of South Africa
}

Doi:10.5901/mjss.2014.v5n23p2049

\begin{abstract}
Parents are the primary educators of their children. They should view themselves as being in partnership with the school, which is then a formalized extension of the family. The partnership has been emphasized by legislation of South African Schools' Act of 1996. This partnership recognizes the mission and responsibility of parents to educate their children and assist in their formal education. By and large, the perception that parents have of education and adulthood determines the role they play in their children's formal education. In the Tsonga community, just as in many other African communities, formal education is regarded as a determinant factor of the level of prosperity, welfare and security which the individual will achieve. The study is qualitative and it investigated the developmental stages of the child in the Foundation Phase at the Tsonga School.
\end{abstract}

\section{Introduction}

During the Foundation Phase period, Curriculum 2005 aims at establishing the critical minimum level of literacy in the mother tongue, the learning of numeracy skills and life skills ((Olivier 1998:2). The Foundation Phase begins with the child's school entry at approximately seven years of age. It ends at the end of Grade Three when the child is about nine years old. During this phase, according to Maier (1978:223), each child is in a "constant state of developmental chang." Although children differ from each other, the basic process of development is the same for every child and the child's chronological age is not the only factor used to judge what development the child has reached.

All children, however, begin at the Foundation School Phase when entering the formal learning situation for the first time.This leads to increased separation from home and family and, as a result, growing independence on the part of the child (Jacobs 1980:52; Very 1979:85). Maier (1978:188) describes the early phase of schooling as involving a shift from dependency on parents to dependency on peers and other adults, including teachers. The child is seen by Maier (1978:190) and Olivier (1998:7) as pushing towards new horizons in the development of his skills, knowledge and emotions during the period now called the Foundation Phase. The child becomes part of a wider group and thus able to relate to an increasing number of people.

It is important to consider what self-concept entails before discussing the developmental stages of the child in the Foundation Phase. This is because the development of the young child's self-concept is strongly affected by the constant feedback from his family and is a vital part of his development in totality. Van den Aardweg and Van den Aardweg (1993:193) declare that the self-concept entails identity, action and self-esteem. Identity refers to "who I am." Action occurs as a result of identity ("I am a singer and I sing"), and self-esteem is the evaluativeaspect of the self-concept, also known as selfworth ('I am an outstanding singer.").

The term "self-concept" is, according to Raath and Jacobs (1993:12), treated synonymously with "self-image", in that self-concept is defined as a "conceptualization or image of the self". Van den Aardweg and Van den Aardweg (1993:214), in their discussion of the self-concept place "self-image" in brackets, also implying thatthese two concepts refer to the same phenomenon.

According to Warren (1992:21), self-concept is cognitively structured because it is a conception.

But, because the self-concept includes attitudes and convictions about the self (which stem from a cognitive organisation of consepts), it is also affective by nature. Warren (1992:30) stresses that self-concept is a structure, that is "the system of concepts available to the person in attempting to define himself".

Jacobs (1980:52) and Vrey (1979:85) argue in the same vein and declare that the child's physical development, emotional development and cognitive development all affect his ability to meet the new demands made on him at school and that young children need to be well looked after. 


\section{Physical Development}

Vorster and De Meillon (1991:68) define physical development as the increase in height and body mass. Development is defined by Lerner and Hultsch (1983:6) as systematic intra-individual changes. Cooper (1991:7) emphasises that development is an organized process. Human. development thus entails all the changes which take place in the human organism between conception and death.

Theorists on child development, such as Hurlock (1978:141), Landreth (1993:21), Michael (1990:319), Piaget (1971:300) and Very (1990:99) point out that during the first four or five years of the child's life, he he gains control over his gross motor movements. He learns, for example, to use his body to walk, run and jump. As he develops physically, he is able to perform these movements with increasing speed, strength and accuracy. Hurlock (1978:145) emphasises that the child becomes able also to perform these movements more economically. He may, for example, use his whole body to throw a ball at first, but eventually will learn to perform this task more effeciently using only his arm. Louw and Louw (2014:9) add that an important aspect of the physical development of the child is motor development, which means the child's gradual development concerning body movements such as sitting, crawling, walking, grasping and later also complex sports activities.

According to Very (1979:88), after approximately the age of five, the vchild begins to gain increasing ontrol over his fine motor co-ordination. This enables him to grasp objects, throw more accurately, catch, write and use tools such as pair of scissors. He becomes able to use different groups of of muscles in a more controlled way. According to Thomas (1990:326), accuracy and speed of movement as well as the ability to perform movements smoothly and automatically increase steadily. Thomas (1990:326) and Michael (1990:323) maintain that the strength of a muscle is related to its cross-sectional area and its composition. Therfare, the changes in strngth that occur during early childhood follow the changes in body size. The steady gain in height and weight parallels the muscle mass and changes in strength between ages six to ten.

The child cannot learn the skilled movements discussed above unless his nervous system and muscles are sufficiently developed. Individual children differ markedly in the rate at which physical development occurs. The opportunity to practise the physical skills which the child is acquiring is also imprtant. Landreth (1993:21) and Thomas (1990:327) point out that the child must be able to exercise physically and play actively in order to develop these skills.

According to Landreth (1993:28), children need to exercise and play because play is the child's natural medium of communication. When children exercise and play, they will understand and come to terms with their environment. Ramarumo (1992:20) emphasises that growing children also need to have sufficient physical vitality and reasonably normal health. Michael (1990:325) and Thomas (1990:327) hold the same vein and point out that, since one's level of fitness is retained for not more than a week or so, continued fitness requires exercise and proper nutrition. Good health will of course also foster resistance to illness. Food and other substances that humans ingest as the fuel for growth and action throughout life obviously exert a strong influence on motor skills.

The child in the Foundation Phase is seen by Vrey (1979:103) as achieving self-actualisation through the mastery of physical skills. Vrey (1990:100) and Nhlapo (1997:24) declare that good motor control makes the child feel physically secure and self-confident. Acceptance by the peer group depends on whether he can run, jump and climb like others in the group. Successful, active participation in games with his peers depends depends on skills such as throwing and catching (Landreth 1993:30).

Hurlock (1978:155) and Rosa (1995:91) maintain that the psychological effects of problems in the area of physical development include feelings of inferiority, envy of others who can perorm these physical tasks well and general feelings of unhappiness and rejection. Contact with the peer group is inhibited and social rejection may result from this. Very (1990:100) states that the child may become timid and afraid to try anything new. The researcher has observed that such children remain dependent on others for help in performing tasks which other children can already perform. Growing children, therefore, need the support of their parents for the establishment of the socialcontext that facilitates maeningful learning as well as acceptance of important differnces in not only intellectual, but also emotional, social and physical development within and among children. Matlou (1993:39) and Lambreth and McCombs (1998:10) emphasise that learners have unique differnces includind emotional states of mind, learning rates, learning styles, stages of development, abilities, talents, feelings of efficacy and other needs. These must be taken into account if all learners are going to be provided with the challenges and opportunities for learning and self-development which they need.

\section{Psycho-Social Development}

Emotions play an important part in the young child's life. They provide the inner force that attracts one person to another, 
or that repels one person from another. Emotions provide provide a sense of feeling with and for others. When positive, they provide a sense of security, help persons cope with frustration, alert them to dangers and prod them into action (Lambert \& McCombs 1998:9).

The pattern of emotional development is generally similar for all, but some factors in the child's life can produce different emotional responses in individual children. Nhlapo (1997:19) acknowledges that a child does not only need to feel safe physically, but he needs to feel sheltered emotionally. Draper (1990:415) and Meyer, Moore and Viljoen (1990:152) state that both the emotions themselves and their patterns of expression change with age, thus, during the child's overall development throughout infancy, childhood, youth and adulthood.The child increasingly gains control over his emotions as he matures. The most frequently expressed emotional reactions and expressions of feelings will generally settle into habits that become driving forces in a child's life.

Hurlock (1978:210), Lamprecht (1990:36) and Mathibe (1992:23) found that signs of emotional maturity in the child include self-control, acceptance and recognition of the emotions which the child is experiencing as well as the ability to express these emotions in a socially acceptable way. According to Draper (1990:417), affection involves the expression of feelings which reflect concern, warmth, caring, sympathy and helpfulness. Young children are especially open about their feelings of affection towards Others. As they reach preadolescence they show less physical affection but demonstrate their feelings through social interaction, confiding in one another and participating in activities together.

During the Foundation Phase significant changes occur in the way in which the child relates to others.

As children leave the shelter of their homes and become part of a larger social group at school, they have the opportunity to relate to an increasing number of people outside their immediate families. Ramarumo (1992:19) describes the child as being thrust"... out of the home and into the peer group."

Vrey (1990:101) points out that the child increasingly seeks relationship with his peers and these peer group relationships become more and more important as he gets older. Very (1990:101) sees this phase as the beginning of the process of the child's emancipation. The growth of the child's independence from adults begins in a slow and steady way and is seen by Vrey (1990:103) as one of the developmental tasks of childhood.

According to Mussen, Conger, Kagan and Huston (1990:535), school-going children influence each other by becoming models on which other children base their own behaviour and by the way in which they interpret and respond to each other's behaviour. Peers thus become increasingly influential in the socialisation process of the child in the Foundation Phase. Draper (1990:419) states that during this phase the child begins to rely on the self as the main source of possibility, energy and safety, and yet remains emotionally grounded in the previous stages (infancy and early childhood). This is a period of search for self-identity and use of the body and brain together as a resource for functioning on a concrete level. Emotions are expressed under greater control as children seek to function as socially accepted human beings, interacting with others and interdependent in relationships.

Children's relationships with their parents are still, however, very important in that their parents can help them or hinder them as they become more independent. Parents' love and support enable children to venture confidently out of the secure home environment and meet the new challenges they face at school. The parents' unconditional acceptance and love will enhance children's self-concept, enabling them to accept themselves, their successes and failures, adapt to new situations and enter into relationships with others. Conditional love and acceptance, on the other hand, will create negative relationships in children and in turn, they could become failures in life. Nhlapo (1997:25) states that when a child is not loved, he becomes anti-social, and may even become truant in order to get the attention of his parents.

Heystek (1998:15), Matlou (1993:39) and Rosa (1995:4) point out that the way in which parents relate to others also provides an example for children in their relationships. During this phase the child becomes less subjective and is able to see other people's point of view. Landreth and McCombs (1998:21) and Vrey (1979:105) point out that the child becomes actively involved in playing with others and generally less egocentric in his approach to them. The child becomes more aware of and concerned with the rules of the particular game being played and fairness and justice become more important to him. Mussen et al., (1990:426) stress this, saying "... through play the child learns to communicate with and relate to others."

Belonging to a group becomes more important to the child in the Foundation Phase and his need for acceptance by his peer group increases. Vrey (1990:102) and Mathibe (1992:7) emphasise that to gain acceptance, must meet the demands of the group. For example, he must be able to keep up with them in physical play and he must be able to wait his turn. The child becomes able to start new activities and persevere until untli they are completed. He becomes able to make decisions for himself and is thus less reliant on others. reliant on adults. 


\section{Cognitive Development}

Cognitive development can be defined as the growing ability of logical thought processes (Vorster \& De Meillon 1991:69). These logical thought processes develop and improve as the child grows older. According to Murray (1990:205), cognition refers to the state of knowing. Gordon and Browne (1993:403) and Bjorklund (1995:3) accept the definition of cognition as:

"... the mental process or faculty children use to acquire and manipulate knowledge. To think is to be able to acquire and apply knowledge. By using conscious thought and memory, children think about themselves, the world and others." The followers of Piaget, such as McShane (1991:5), Grolnick and Slowiaczek (1994:239) and Nelson (1996:5) agree that children undergo stages of cognitive development, namely, the sensory-motor stage where Ireaning occurs through use of senses and motor activities; the pre-operational stage where the words or objects represent people and other objects; the concrete operational stage where real objects are needed by the child before he can draw conclusions; and the formal operational level where the thinking of the child is abstract.

Nelson (1996:5) emphasises that the cognitive task of the human child is to make sense of his or her situated place in the world in order to take a skilful part in its activities. During the Foundation Phase the child shows increased interest in and comprehension of the world around him. He begins begins to see reality in a more objective way. At this stage the child explores his world actively and gains both new knowledge and skills. He begins to master the basic scholastic skills. Success in this area is very important to him and failure leads to feelinfs of inferiority.

Hammil and Bartel (1990:296), Mussen et al., (1990:276), Nelson (1996:11) and Piaget (1971:300) emphasise that during the concrete operational stage, the child becomes able to carry out mental activities that demonstrate the properties of flexibility and reversibility. The child can now understand that the action of taking some of a given number of objects from a jar can be reversed by putting the the same number of objects back into the jar.This kind of understanding is thought to be necessary for the child to understand the relationship between reverse operations such as addition and subtraction in numeracy.

Further characteristics of the child's thinking during the stage of concrete operations include decentration, which is defined by Mussen et al., (1990:276) as the ability to "... focus attention on several attributes of an object or event simultaneously and understand the relationships among among dimensions or attributes." There is also a shift from relying solely on that which is perceived perceived to the use of logical principles. Children become able to understand that qualities of an object such as its mass remain the same even when changes are made in the shape of that object. They can also use the principle of conservation in order to understand that the number of objects in two equal groups remains the same even when one of the groups is is arranged in a different way (Rosa 1995:52).

The child also becomes able to arrange a group of objects according to a given characteristics, for example, from heaviest to lightest. According to Mussen et al., (1990:278), Rosa (1995:54) and Vrey (1990:115), when comparing objects, the child no longer thinks in absolute terms. He becomes able to compare two or more objects. When comparigng three buildings, for example, the child is able to identify them as a tall building, a taller building and the tallest building

Hammil and Bartel (1990:295) and Mussen et al., (1990:230) agree that, during the stage of concrete operations, the child is also able to classify objects in a hierarchical way. In addition, the child is able to understand that an object may belong to more than one category at any given time category at any given time.

\section{Reseach Methodology}

The researcher used a qualitative study to obtain the information. David \& Silverman (2011) maintain that a qualitative study meets the interpretive researcher's purpose of understanding situations that are complex. The qestionnaire was used to collect data from Tsonga parents of the Grade Two learners and their teachers at the pilot school in Mamelodi. Levin \& Rock (2003:43) hold the same view that interpretive social research emphasises the complexity of human beings and attempts to construct and understand their worlds.

\section{Discussion and Conclusions}

According to Mussen et al., (1990:280) and McShane (1991:7), the child in the Foundation Phase thus shows marked differences in the way in which he thinks when compared to the preschool child. He is still, however, reliant on concrete objects and the relationships between them rather than on abstractions. This implies that the child's thinking is, to a large 
extent, still restricted to the concrete level. Facilitation at home as well as at school to be aligned with the particular learning style and needs of children in this age group, is als advisable.

His ability to use language to express himself increases and language is seen as the medium through which thought and reasoning develop. According to Grolnick and Slowiaczek (1994:241) and Rosa (1995:53), the child also begins to learn the difference between right and wrong and values become more important to him. The example of others is seen as a critical factor in the development of the child's value system.

As the child develops, his cognitive skills also widen. He begins to see things differently. The self-concept is highly meaningful to the learner, whether it is based on high or low esteem. The teaching style selected by the teacher and the learning environment at home must be such that it enables the learner to see himself or herself as successful at this stage. The taeching style and learning environment must be oriented towards the development of a positive scholastic self-concept. Hartline (1993:19) maintains that the self-concept is wider than self-esteem. We may think of self-esteem as a circle enclosed within the wider circle of self-concept or we may think of self-esteem as the evaluative component of the self-concept.

\section{References}

Bjorklund, DF. 1995. Children's thinking: Developmental function and individual differences (2nd ed.). U.S.A.: Brooks/Cole Ublishing Company.

David, S. \& Silverman, D. 2011. Qualitative research, (3rd ed.). London: Sage Publiication, Ltd.

Draper, W. 1990. The Encyclopaedia of Human Development and Education. Emotional Development. New York: Pergamon Press.

Gordon, AM. \& Browne, KW. 1993. Foundations in Early Childhood Education (3rd ed.). Albany, New York: Demar

Grolnick, WS. \& Slowiasczek, ML. 1994. Child Development. Parents' involvement in children's schooling: A multidimensional conceptualization and motivational model. Journal of Educational Psychology, 65:237-252.

Hammil, DD. \& Bartel, NR. 1990. Teaching students with learning and behaviour problems. Allyn \& Bacon Inc.

Hartline, JH. 1993. Me? A curriculum for teaching self-esteem through an iterest centre. Cheltenham, Victoria: Hawker Brownlow Educational.

Heystek, J. 1998. Empirical Research: Parental involvement in school activities. Unpublished research report. Pretoria: University of Pretoria.

Hurlock, EB. 1978. Development Psychology. New York: McGrow-Hill.

Lambert, NM. \& McCombs, BL. 1998. How students learn. Reforming schools through learner-centred education. U.S.A.: American Psychological Association.

Lamprecht, C. 1990. Every child a winner. Cape Town: Tafelberg.

Landreth, GL.1993. Child-centred play therapy. Journal of Elementary School Guidance and Counselling, 23(1): 17-29.

Lerner, RM. \& Hultsch, DE, 1983. Human development: a life-span perspective. U.S.A: McGraw-Hill.

Levin, B. B. \& Rock, T. C. 2003. The effects of collaboration action research on preservice and experienced teacher partners in professional development schools: Journal of Teacher Education, 54: 135-149.

Louw, D. \& Louw, A. 2014. Child and adolescent development (2nd ed.). Bloemfontein: ABC Press, Goodwood.

Maier, HW. 1978. Three theories of child development, (3rd ed.). New York: Harper \& Row.

Mathibe, ID. boy's The black adolescent perception and constitution of lifeworld in an urban area. M Ed. Thesis. Pretoria: University of Pretoria.

Matlou, RE. 1993. Parental responsibilty and educative teaching in Bophuthatswana schools. MEd. Fundamental pedagogics. Pretoria: University of Pretoria.

McShane, J. 1991. Cognitive Development: An information processing approach. Cambridge: Basic Blackwell.

Meyer, WF., Moore, C, \& Viljoen, HG. 1990. Personality theories. Johannesburg: Lexicon Publishers.

Murray, FB. 1990. The Encyclopaedia of Human Development and Education: Theory,research and studies: Cognitive Development. New York: Pergamon Press.

Mussen, PH., Conger, JJ., Kagan, \& Huston, AC.1990. Child Development and personality. New York: Harper \& Row.

Nelson, K. 1996. Language in cognitive development. The emergence of the mediated mind. New York: Cambridge University Press.

Nhlapo, RV. 1997. The role of parents. Med. Mini Dissertation. Johannesburg: Rand Afrikaans University.

Piaget, J. 1971. Theories of Child development. The psychology of the child. New York: Basic Books.

Raath, MC, \& Jacobs, LJ. 1993. Dynamics of the self-concept. Pretoria: Academica.

Ramarumo, MM. 1992. The adequacy of literacy education for school beginners from literate and semi-literate homes:.A case study in rural Venda. DEd-Thesis. Pretoria:University of Pretoria.

Rosa, CM. 1995. The influence of parental involvement, discipline and choice of valueson the scholastic achievement of secondary school pupils with special reference to the father. Med Thesis.Pretoria: University of South Africa.

Thomas, RM. 1990. The Encyclopaedia of Human Development and Education. Theory, Research and Studies: Motor Development. New York: Pergamon Press.

Van den Aardweg, EM, \& Van de Aardweg, ED. 1993. Psychology of Education. A dictionary for students, (revised $2^{\text {nd }}$ ed.). Pretoria: E \& 
E Enterprises.

Vrey, JD. 1971. The self-actualising educand, (1st ed.). Pretoria: University of South Africa.

Vorster, PJ. \& De Meillon, N. 1991. Study guide for empirical education. Pretoria: University of South Africa.

Warren, M. 1992. Die aard van betekenisgewing in die identiteitvestiging van adolessente met probleme. DEd Thesis. Pretoria: University of South Africa. 